Научная статья

УДК 332.145

DOI: $10.18101 / 2304-4446-2021-2-104-108$

\title{
ВОЗВРАТНАЯ МИГРАЦИЯ \\ КАК МЕРА СОЦИАЛЬНО-ЭКОНОМИЧЕСКОГО РАЗВИТИЯ \\ СЕЛЬСКИХ ТЕРРИТОРИЙ
}

\author{
(c) Янтранов Александр Евгеньевич \\ кандидат экономических наук \\ yantran@mail.ru
}

(C) Субанаков Георгий Юрьевич

кандидат экономических наук

subgeorge@mail.ru

Бурятский государственный университет имени Доржи Банзарова

Россия, 670000, г. Улан-Удэ, ул. Смолина, 24а

\begin{abstract}
Аннотация. Для регионов-«доноров» человеческого капитала миграционный отток накапливает комплекс сложных проблем в экономике. В статье был проведен анализ миграционного движения в Республике Бурятия за период с 2014 по 2019 г., в ходе которого наблюдалось преобладание внутрирегионального перемещения населения республики, т. е. оно мигрирует в региональный административный центр г. УланУдэ и пригородные населенные пункты. По результатам выборочного опроса выделяются следующие группы сегментов населения с достаточным миграционным потенциалом: первая группа — горожане зрелого возраста (от 45 лет), достигшие пределов профессионального роста и желающие заняться трудовой деятельностью на своей малой сельской родине, вторая - горожане, которые не удовлетворены жизнью в городе, но смене места жительства препятствуют финансовые трудности, третья группа - трудовые резервы, находящиеся в самих сельских поселениях. Для каждой выделенной группы сегментов населения предлагаются меры, направленные на предотвращение дальнейшего исхода трудоспособного сельского населения в города.

Ключевые слова: стратегия развития, миграционная политика, институты, региональная экономика, человеческий капитал, сельское хозяйство, Республика Бурятия, госпрограмма, трудовые ресурсы.
\end{abstract}

\section{Для цитирования}

Янтранов А. Е., Субанаков Г. Ю. Возвратная миграция как мера социальноэкономического развития сельских территорий // Вестник Бурятского государственного университета. Экономика и менеджмент. 2021. № 2. С. 104-108.

Миграция продолжает оставаться одним из главных факторов, влияющих на развитие экономик регионов и страны в целом. И если стремительно увеличивающиеся массовые потоки людей заставляют обращать внимание «реципиентов» на контроль за регулированием миграционных процессов, то для «доноров» миграция, являясь отражением комплекса проблем, начиная с периферийности территории, дисбаланса на рынке труда, заканчивая отсутствием образовательных возможностей, становится барьером в развитии экономики, основанной на высо- 
A. Е. Янтранов, Г. Ю. Субанаков. Возвратная миграция как мера социальноэкономического развития сельских территорий

кокачественном человеческом капитале. Именно ко второй категории территорий, имеющих противоречивые характеристики, относится Республика Бурятия.

Миграционный отток из региона в России происходит по всем направлениям, преимущественно в западную сторону, не ограничиваясь пределами России. С начала 1990-х гг. регион покинуло порядка 400 тыс. человек. И в этом потоке доля молодёжи достигла 40\% [1, с. 53].

Таблица 1

Межрегиональная миграция населения в Республике Бурятия за 2015-2019 гг., чел. ${ }^{1}$

\begin{tabular}{|c|c|c|c|c|c|c|c|}
\hline \multirow[t]{2}{*}{ Показатель } & \multirow[t]{2}{*}{2015} & \multirow[t]{2}{*}{2016} & \multirow[t]{2}{*}{2017} & \multirow[t]{2}{*}{2018} & \multirow[t]{2}{*}{2019} & \multicolumn{2}{|c|}{$\begin{array}{c}\text { Изменение } \\
2019 \text { г. к } 2015 \text { г. }\end{array}$} \\
\hline & & & & & & чел. & $\%$ \\
\hline Прибывшие & 13118 & 12984 & 13394 & 12863 & 13104 & -14 & $-0,1$ \\
\hline Выбывшие & 15793 & 16690 & 16531 & 17025 & 14276 & -1517 & $-9,6$ \\
\hline $\begin{array}{l}\text { Миграционный } \\
\text { прирост, убыль }\end{array}$ & -2675 & -3706 & -3137 & -4162 & -1172 & -1503 & 56,2 \\
\hline
\end{tabular}

В то же время, при рассмотрении динамики структуры миграционного движения в Республике Бурятия, наблюдается преобладание внутрирегиональных перемещений, которые за период 2014-2019 гг. достигали 64-68\% от общей структуры (рисунок 1).

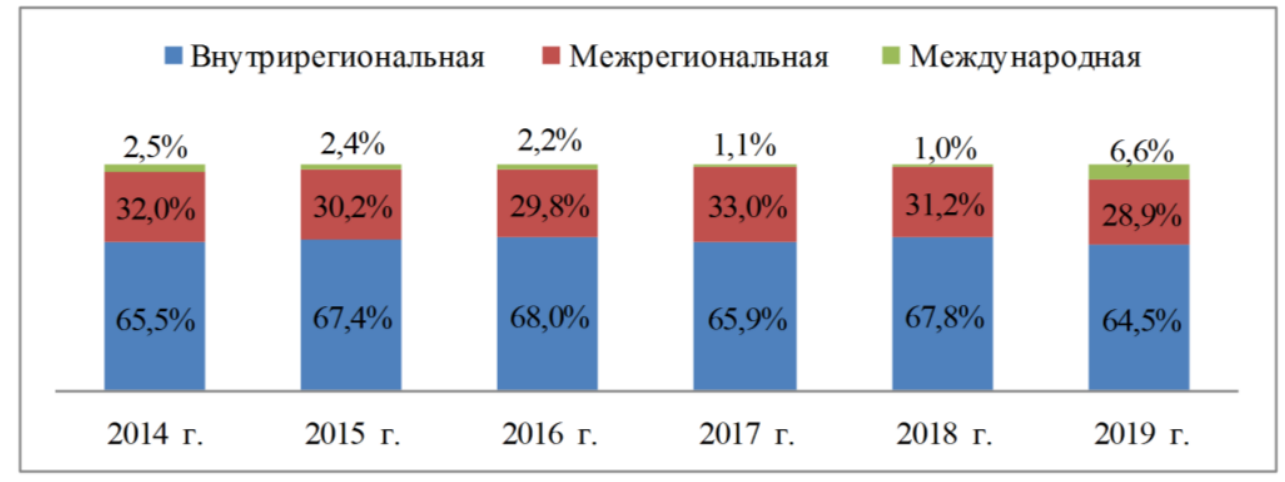

Рис. 1. Структура миграционного притока в Республике Бурятия, \%

Внутрирегиональные перемещения населения Республики Бурятия соответствуют центростремительному общероссийскому явлению: население мигрирует в региональный административный центр г. Улан-Удэ и пригородные населенные пункты. Аналогичная тенденция миграционного движения характерна для всех субъектов Дальневосточного федерального округа. Внутрирегиональная миграция - меньшее зло, чем исход населения в другие регионы страны и тем более другие страны, означающая утечку «мозгов», «рук» и истощение человече-

\footnotetext{
1 Территориальный орган Федеральной службы государственной статистики по Республике Бурятия. Миграция. Демография. URL: https://burstat.gks.ru/demo (дата обращения: 20.03.2021). Текст: электронный.
} 
ского капитала, который так необходим для хозяйственного освоения восточных регионов России. Тем не менее стоит отметить и возникновение последствий социального и криминального характера по факту центростремительной миграции [2].

Принятая госпрограмма «Комплексное развитие сельских территорий» от 31 мая 2019 г. № 696 акцентирует внимание на региональной проекции и вселяет надежду на преодоление демографического кризиса и создание благоприятных условий жизнедеятельности на сельских территориях. Однако учитывая, что социально-демографический фактор является основополагающим в деле предотвращения дальнейшего исхода трудоспособного сельского населения в города, необходимы дополнительные меры и действия для привлечения трудовых ресурсов и повышения человеческого капитала. Одной из таких мер является организация возвратной миграции в село городских жителей. Возвратная миграция это переезд человека в родную страну или место постоянного проживания после проживания на другой территории (обычно не менее 12 месяцев) [3].

По результатам выборочного опроса и дальнейшего анализа выделяются следующие сегменты населения. В первую очередь это горожане первого и второго поколений зрелого возраста (от 45 лет), достигшие пределов профессионального роста и желающие заняться трудовой деятельностью на своей малой сельской родине.

Достаточный миграционный потенциал и у тех категорий горожан, которые по разным обстоятельствам не удовлетворены жизнью в городе, но смене места жительства препятствуют финансовые трудности. Для таких категорий граждан необходима комплексная программа трудоустройства в сельской местности. Один «дальневосточный гектар» - стимул недостаточный. Необходимы инструменты субсидирования (невозвратные средства), ипотечного кредитования, лизинга и дальнейшей институциональной поддержки их последующей деятельности на селе.

Третья категория трудовых резервов находится в самих сельских поселениях. Это та категория граждан трудоспособного возраста, имеющая профессию, квалификацию, но не имеющая способностей вести предпринимательскую деятельность. Для этой категории безработных наилучший вариант - трудоустройство в сложившихся организациях или вновь создаваемых муниципальных предприятиях на основе активов (земли, оборудование), принадлежащих муниципальному образованию. Юридические формы предприятия могут быть различными исходя из условий, установленных законодательством.

Приток трудовых ресурсов необходимо дополнить качественным человеческим капиталом. В отечественной истории эту задачу коммунистическое руководство СССР решало путем мобилизации инженеров, специалистов и рабочих на строительство нового колхозно-совхозного уклада в начале 30 -х гг. XX в. [4, c. 290]. Проведенная акция закрепилась в истории как «Движение двадцати пяти тысячников». Возможность повторения опыта зависит от политической воли руководства региона и стимулирующих инструментов, включая действующие, такие как «Дальневосточный гектар», «Льготная дальневосточная ипотека» и др. Агентами влияния нового подхода к развитию села могут стать вышеперечисленные категории «возвращенцев» и представители «Движения двадцати тысяч- 
A. Е. Янтранов, Г. Ю. Субанаков. Возвратная миграция как мера социальноэкономического развития сельских территорий

ников XXI века», что может обусловить начало нового этапа развития сельских территорий, как это уже было в начале XX в.

Сложная социально-демографическая ситуация складывается в таких дальневосточных регионах, как Республика Бурятия. Основными проблемами миграции Республики Бурятия являются отток трудоспособного, преимущественно молодого, населения, урбанистические процессы внутрирегиональных миграционных потоков, миграционное давление иностранной рабочей силы. При этом текущее состояние сельских территорий иначе, чем упадком, назвать нельзя. Реакция населения на сложную социально-экономическую ситуацию трансформируется в миграцию в районные центры и города внутри Бурятии и за ее пределы.

Вселяют оптимизм принятие и реализация отдельных государственных программ, направленных на развитие сельских территорий. Однако учитывая важность социально-демографических причин предотвращения дальнейшего миграционного оттока трудоспособного населения из сел, необходимы дополнительные меры и действия для пополнения трудовых ресурсов и развития человеческого капитала в сельских территориях.

\section{Литература}

1. Бюраева Ю. Г. Молодежная миграция в Республике Бурятия: направленность потоков и причины // Социологические исследования. 2020. № 10. С. 52-62. Текст: непосредственный.

2. Шевцова Е. В., Дмитриева А. К. Миграционная политика Республики Бурятия: сценарные подходы // Вестник Тюменского государственного университета. Социальноэкономические и правовые исследования. 2016. Т. 2, № 2. С. 59-71. Текст: непосредственный.

3. Цыренов Д. Д., Мадиева М. Г. Особенности возвратной миграции молодежи в Республику Бурятия // Вестник Бурятского государственного университета. Экономика и менеджмент. 2017. № 1. С. 54-58. Текст: непосредственный.

4. Троценко Н. Д. Проблемы адаптации 25 -тысячников в условиях коллективизации западно-сибирской деревни (1930-1933 годы) // Вестник НГУ. Сер.: История, филология. 2010. Т. 9, вып. 1. С. 286-291. Текст: непосредственный.

Статья поступила в редакциию 27.04.2021; одобрена после рецензирования 28.04.2021; принята к публикации 28.04.2021. 
RETURN MIGRATION AS A MEASURE FOR SOCIO-ECONOMIC DEVELOPMENT OF RURAL TERRITORIES

\author{
Aleksandr E. Yantranov \\ Cand. Sci. (Econ.) \\ yantran@mail.ru \\ Georgiy Yu. Subanakov \\ Cand. Sci. (Econ.) \\ subgeorge@mail.ru \\ Dorzhi Banzarov Buryat State University \\ 24a Smolina St., Ulan-Ude 670000, Russia
}

Abstract. Migration outflow from the regions that are "donors" of human capital accumulates a complex of problems in the economy. The article analyzes the migration movement in the Republic of Buryatia for the period from 2014 to 2019, when there was a predominance of intraregional population flow, in particular, migration to Ulan-Ude as a regional administrative center and suburban settlements. The results of a sample survey allowed us to distinguish the following groups of population with sufficient migration potential: the first group - urban dwellers of mature age (from 45 years old) who have reached the limits of advancement and who want to engage in labour activities in their rural homeland, the second - urban dwellers who are not satisfied with life in the city, but the change of place of residence is hindered by financial difficulties, the third group is labour reserves located in the rural settlements themselves. For each abovementioned group of population we have proposed measures to prevent its further migration to cities.

Keywords: development strategy, migration policy, institutions, regional economy, human capital, agriculture, the Republic of Buryatia, state program, labour resources

\title{
For citation
}

Yantranov A. E., Subanakov G. Yu. Return Migration as a Measure for Socio-Economic Development of Rural Territories. Bulletin of Buryat State University. Economy and Management. 2021; 2: 104-108 (In Russ.).

The article was submitted 27.04.2021; approved after reviewing 28.04.2021; accepted for publication 28.04.2021. 